\title{
Universiteit
}

Leiden

The Netherlands

\section{An old problem in a new light: elemental and lead isotopic analysis of Luristan Bronzes}

Oudbashi, O.; Rademakers, F.W.; Vanhaecke, F.; Degryse, P.A.I.H.; Hasanpour, A.; Bahadori, S.

\section{Citation}

Oudbashi, O., Rademakers, F. W., Vanhaecke, F., Degryse, P. A. I. H., Hasanpour, A., \& Bahadori, S. (2021). An old problem in a new light: elemental and lead isotopic analysis of Luristan Bronzes. Journal Of Archaeological Science Reports, 39.

doi:10.1016/j.jasrep.2021.103163

Version: $\quad$ Not Applicable (or Unknown)

License: $\quad$ Leiden University Non-exclusive license

Downloaded from: https://hdl.handle.net/1887/3256981

Note: To cite this publication please use the final published version (if applicable). 


\section{An Old Problem in a New Light: Elemental and Lead Isotopic Analysis of 2 Luristan Bronzes}

3

4 5 6 7 8 9 10 11 12 .

\author{
Omid Oudbashi ${ }^{1 *}$ \\ Frederik W. Rademakers ${ }^{2,3}$ \\ Frank Vanhaecke ${ }^{4}$ \\ Patrick Degryse ${ }^{2,5}$ \\ Ata Hasanpour 6 \\ Sepehr Bahadori ${ }^{1}$
}

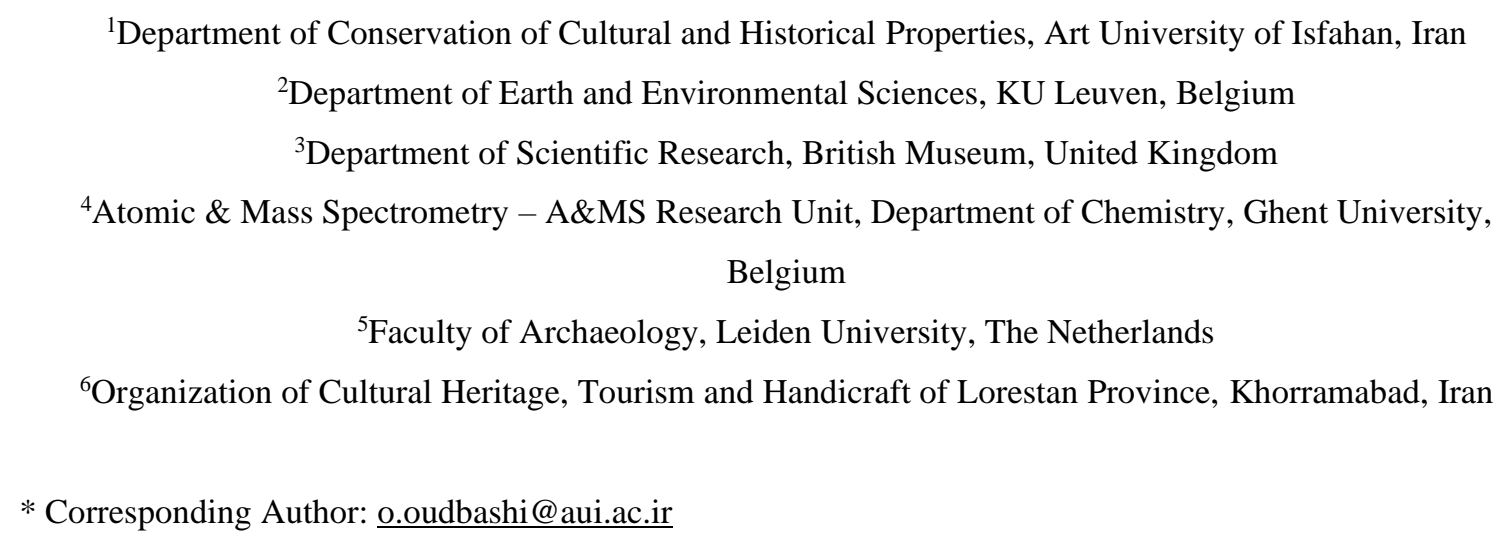
3 4 5 6 7 8 9 0 1 


\section{An Old Problem in a New Light: Elemental and Lead Isotopic Analysis of 2 Luristan Bronzes}

Abstract

The emergence and provenance of the Luristan Bronzes has been a subject of interest for many decades. This paper presents the results of elemental and lead isotopic analysis of a series of Luristan Bronzes discovered from recent excavations in the Sangtarashan sanctuary, as well as an extensive comparative study on technology and provenance of the Luristan Bronzes. This study was performed in order to better understand tin bronze production technology in the Luristan region during the Iron Age. It focuses on the artefacts themselves, as no mining or production evidence has been discovered in Luristan so far. For this purpose, 46 samples from different pieces of thin sheet vessels from Sangtarashan were analysed by inductively coupled plasma-optical emission spectroscopy (ICP-OES) for their elemental composition and by multi-collector inductively coupled plasma-mass spectroscopy (MC-ICP-MS) for their lead isotopic composition. The results of elemental analysis showed that tin bronze with variable tin content was used to produce these artefacts. The comparative study of the alloy composition also shows that tin bronze may have been the main material to produce ritual artefacts during the Iron Age of western Iran. Furthermore, the lead isotope ratios of the Sangtarashan artefacts partially overlap with those of different copper ore deposits on the Iranian Plateau, including deposits close to Luristan (such as Deh Hosein) and ore deposits further away, in central and eastern Iran. In fact, the results revealed that it is not possible at this stage in the research to identify one specific ore deposit or region as the source of copper for tin bronze metallurgy during the Iron Age of Luristan. Thus, the research suggests that ancient metalworkers apparently used different copper sources to produce the bronze artefacts specific to the region of Luristan in western Iran.

\section{Keywords}

Luristan Bronzes, Sangtarashan sanctuary, Iron Age, Tin bronze, Alloying, Provenance analysis 


\section{Introduction}

2 For a century, the Luristan Bronzes have been an enigma in the prehistoric archaeology of the Near East. Although they appeared in 1920's on the antiquities market in the western

4 world as artefacts attributed to an ancient region in western Iran, namely Luristan

5 (Overlaet, 2006; Muscarella, 1988: 112; Muscarella, 1990: 478; Moorey, 1964:72), their

6 archaeological context remained unknown until about the 1960s and 1970s, when it was

7 illuminated by a number of archaeological excavations of necropoli, particularly by the

8 Belgian Archaeological Mission in Iran (BAMI) under supervision of Louis Vanden

9 Berghe in Pusht-i Kuh, Luristan (Haerinck and Overlaet, 2004a; Haerinck, 2009;

10 Muscarella, 1988).Various historical and archaeological studies and excavations during the

11 1930s up to the 1970s in western Iran and central Zagros has led to some level of

12 understanding of the probable origins of the Luristan Bronzes (e.g., Schmidt et al., 1989;

13 Calmeyer, 1969; Godard, 1931; Goff, 1968; Moorey, 1969; Muscarella, 1988a; 1988b;

14 Vanden Berghe, 1971; 1981; 1987; Haerinck and Overlaet 1998; 1999; 2004b; Haerinck et

15 al., 2004). One important issue in the archaeology of the Luristan Bronzes is that the

16 majority of artefacts attributed to this region in museums worldwide have not been obtained

17 from controlled excavations, but rather from illegal activities, and thus their origin cannot

18 be confirmed (Overlaet, 2004; 2005; 2006). It should be noted that the artefacts discovered

19 from earlier archaeological excavations are not numerous (Muscarella, 1988a; 1990).

20 Examples include Luristan Bronzes excavated from Surkh Dum, an Iron Age sanctuary

21 (Schmidt et al., 1989; Overlaet, 2011), War Kabud graveyards (Haerinck and Overlaet,

22 2004a) and Baba Jan (Goff, 1968). Of course, recent archaeological work in the Luristan

23 region has led to the discovery of significant numbers of bronzes in particular from

24 Sangtarashan and Baba Jilan (Hashemi et al., 2021; Hasanpur et al., 2015).

25 Careful assessment of archaeological excavations in ancient Luristan showed that the

26 Luristan Bronzes are artefacts of ritual significance that have been deposited in graves and

27 sanctuaries during the Iron Age, ca. 1500-500 BCE, or according to more recent dating, ca.

28 1300-650 BCE in western Iran (Overlaet, 2004; 2005; 2006). Still, there are some

29 unanswered (or incompletely answered) questions about the Luristan Bronzes such as:

30 Which peoples or tribes manufactured these artefacts? Where were they produced? What 


\section{Sangtarashan Archaeological Site}

22 Recent archaeological research in the Pish-i Kuh region of Luristan (Figure 1a and 1b) has

23 led to the identification of new Iron Age sites, such as Sangtarashan and Baba Jilan, at

24 which metal artefacts were discovered including different types attributed to the Luristan

was the metallurgical technology underlying their production? Which ore resources provided the raw materials, i.e., tin and copper, for the production of these artefacts? Of course, it should be mentioned that a series of archaeological and analytical studies have been undertaken during recent decades to address these questions (e.g., Fleming et al., 2005; 2006; Oudbashi and Davami, 2014; Oudbashi and Hasanpour 2018; Oudbashi et al., 2016a; Nezafati, 2006; Moorey, 1964), but the technology and provenance of tin bronze production in the Iron Age of Luristan remains an underresearched topic in the archaeology of prehistory on the Iranian Plateau.

The aims of this paper are first to offer a preliminary overview of the technology of tin bronze production in the Iron Age of western Iran with particular reference to Luristan, and secondly to study the metallurgy of the excavated Sangtarashan bronzes and their provenance. The technological study is based, in part, on the chemical analysis of a series of bronze artefacts from the Sangtarashan sanctuary and its comparison to the available data on other artefacts from Luristan and elsewhere in the wider region. Provenance is assessed using lead isotopic analysis of a group of the Sangtarashan artefacts and by comparison with available lead isotope ratio data from other artefacts from prehistoric sites and ore deposits on the Iranian Plateau. Thus, this paper aims to shed new light on tin bronze technology in Luristan during the Iron Age by combining new and already available analytical data. Bronzes' style such as vessels, finials, weapons and decorative artefacts (Hashemi et al., 2021; Oudbashi et al., 2013; Malekzadeh et al., 2017; Hasanpur et al., 2015).

Sangtarashan is located southeast of Khorramabad, the capital of the modern Lorestan province (Figure 1b). The Sangtarashan (or Patakht-e Sangtarashan) site is located at the north of the Sangtarashan village in the Papi district of Khorramabad county (geographic coordinates $33^{\circ} 15^{\prime} 15^{\prime \prime} \mathrm{N}$ and $48^{\circ} 33^{\prime} 748^{\prime \prime} \mathrm{E}$ ), about $50 \mathrm{~km}$ southeast of Khorramabad city 
1 (Figure 2a). It lies $1650 \mathrm{~m}$ above sea level in the southern part of the Luristan's Pish-i Kuh

2 region. The archaeological site is located in a flat farming area on the southern slope of a mountain. Farming activities have covered the archaeological remains over time with a

4 partially thick layer of dark soil. The area of the archaeological site is estimated to be 5 around one hectare (Figure 2b). It has been excavated in six seasons from 2006 to 2011, 6 which has led to the discovery of an Iron Age sanctuary constructed from stone fragments 7 (Figure 2b and 2c) in which numerous metallic artefacts attributed to the Luristan Bronzes 8 were found. The excavation site report is soon to be published by Dr. Zahra Hashemi and 9 colleagues (Dr. Ata Hasanpour and Dr. Mehrdad Malekzadeh) and earlier preliminary 10 publications on the excavations include: Oudbashi et al., 2013; Oudbashi et al., 2016a;

11 Malekzadeh et al., 2017; 2018; Hasanpur and Malekzadeh, 2019). Archaeological

12 excavations yielded no evidence of graves, but rather, more than 2000 diverse metal 13 artefacts attributed to the Luristan Bronzes' style, ranging in character from simple to 14 sophisticated types. These were all found associated with several architectural structures at the site (Figure 3) (Malekzadeh et al., 2017; Oudbashi et al., 2013). Also, results of ${ }^{14} \mathrm{C}$ dating on two animal bone samples from the site provided two dates of ca. $15^{\text {th }}-14^{\text {th }}$ and late $9^{\text {th }}$ - early $8^{\text {th }}$ centuries BCE i.e., ranging from Iron Age I to early Iron Age III (Hashemi et al., 2021). Archaeological finds including the metal artefacts and the simple stone architecture suggest that the site's main period of activity is Iron Age II-III. Accordingly, 20 the site has been identified as an Iron Age II-III sanctuary and is compared with the only 21 other known Iron Age sanctuary site discovered in Luristan, in the Pish-i Kuh, namely 22 Surkh Dum (or Surkh Dum-e Lori), excavated by E. F. Schmidt in the 1930s (Schmidt et 23 al., 1989).

24 The metal artefacts from Sangtarashan include different types made of a tin bronze alloy 25 that represent well the variability in elemental composition of the Luristan Bronzes. In total 262349 artefacts were found in Sangtarashan during the six seasons of excavation as 27 associated groups (caches) or as scattered finds. One hundred and two artefacts, mainly 28 metallic, were found in sixteen caches (Figure 3a and 3b). The rest (2247 artefacts), 29 belonged to the second group, that of scattered finds. A significant number of the excavated 
artefacts were metallic artefacts, including numerous bronzes and some iron artefacts (Malekzadeh et al., 2017; 2018; Hasanpur and Malekzadeh, 2019).

Some artefacts from Sangtarashan were analysed by microscopic and elemental analysis methods, showing that binary tin bronze alloys were used to produce these artefacts (Oudbashi et al., 2013; Oudbashi and Davami, 2014; Oudbashi et al., 2016a). Furthermore, as noted above, other artefacts from the Luristan Bronzes collection from different archaeological sites or unprovenanced collections were analysed by various researchers using different elemental analysis and microscopic methods to understand the alloy composition and manufacturing methods. The data reported clarified some technological aspects of this invaluable metal collection, such as strongly variable tin concentrations in similar artefacts. Nevertheless, the technology of tin bronze metallurgy of the Luristan Bronzes and the provenance of the raw materials used has not been studied widely and the Sangtarashan collection provides a rare opportunity to perform an extensive analytical study on the technology and provenance of the Luristan Bronzes.

\section{Materials and Methods}

\section{Samples}

A total of 46 samples from 31 broken metal vessels excavated during different seasons of the Sangtarashan excavation were selected (Figure 4). These vessels are broken artefacts that could be sampled easily by cutting a small fragment from broken pieces using a jeweller's saw. The very thin corrosion crust from the surface was mechanically removed before further treatment of each sample. These corrosion crusts were studied previously and revealed to be very thin (less than $100 \mu \mathrm{m}$ overall) without indications of active corrosion in the burial environment such as significant amounts of chlorine (Oudbashi et al., 2016b; Oudbashi, 2018). The samples include vessel edges (7 samples), bodies (29 samples), spouts (3 samples), a base (one sample) and a handle (one sample) and other types of metallic pieces, such as a simple pin or rod (one sample) and shield pins (4 samples). Sample details are presented in Table 1. In some vessels, the body and the edge were both selected for analysis because the artefact was heavily fragmented and transformed into many pieces and, in many cases, the appearance of the edges and bodies was different 
enough to suggest that these pieces may originate from different artefacts (e.g., ST.10-10 and ST.20-10 see Table 1) although other artefacts show similar appearance in their pieces including edge and body (e.g., ST.01-10, ST.03-10, ST.04-10 and ST.08-10, see Table 1). Other pieces such as pins, spouts and handles are obviously made of separate pieces (e.g., ST.02-10, ST.18-10 and ST-KH, see Table 1). Some of the samples were previously analysed by elemental analysis methods such as Inductively Coupled Plasma - Optical Emission Spectroscopy (ICP-OES) and Scanning Electron Microscopy - Energy Dispersive Spectroscopy (SEM-EDS) (Oudbashi et al., 2013; Oudbashi and Davami, 2014; Oudbashi et al., 2016a), but some others have not been analysed before (10 samples) and their compositions are reported for the first time here. Nevertheless, all samples were analysed here again to obtain comparable results, as the majority of previous results were obtained by semi-quantitative SEM-EDS whereby trace elements were not determined.

\section{Analytical Methods}

To identify the elemental composition of the metal artefacts, quantitative elemental analysis was performed using ICP-OES to determine the concentrations of major, minor and trace elements. The detection limit of the method was 0.001 weight percent (wt.\%). For the purpose of ICP-OES analysis, about $0.5 \mathrm{~g}$ of the metallic core of each artefact was taken and the corrosion layer was removed mechanically. Subsequently, the sample was first dissolved in pure aqua regia $\left(\mathrm{HCl}+\mathrm{HNO}_{3}, 3: 1\right)$ and then diluted after complete dissolution. The solution thus obtained was measured using a Varian 735 model ICP-OES instrument in operation at the Zarazma Mineral Studies Company, Tehran.

Separate samples (ca. $0.05 \mathrm{~g}$ ) from the same artefacts were dissolved for lead isotopic analysis at the Geochemical Laboratory of KU Leuven (Belgium). Dissolved samples were taken to a class-10 clean lab facility at Ghent University (Belgium) for chromatographic lead isolation (De Muynck et al. 2008) relying on the use of Pb-SPEC resin (Eichrom Technologies). Single-collector ICP-MS was used to determine the Pb concentration to evaluate target element recovery and allow adequate dilution, such that the $\mathrm{Pb}$ concentration $(150 \mu \mathrm{g} / \mathrm{kg})$ in all sample and standard solutions measured matched within \pm 12\%. Lead isotope ratios were determined using a Thermo Scientific Neptune Multi- 
1 Collector - Inductively Coupled Plasma - Mass Spectrometer (MC-ICP-MS) in operation

2 at Ghent University. The bias introduced by instrumental mass discrimination was

3 corrected for by using a combination of internal correction (with $\mathrm{Tl}$ as an internal standard

4 and following Russell's law) and external correction, based on replicate sample-standard

5 bracketing measurements of the NIST SRM 981 common lead standard (using the

6 commonly accepted isotope ratio values from Galer and Abouchami (1998). Full details for

7 sample preparation and analytical procedures are provided in Rademakers et al. (2020).

8 Relative errors ( $\sigma$, calculated from 60 replicate measurements) on the data presented here

9 are better than $0.02 \%$ for the corrected ratios to ${ }^{204} \mathrm{~Pb}$, and better than $0.005 \%$ for ratios to $10 \quad{ }^{206} \mathrm{~Pb}$.

\section{Results and Discussion}

13 Elemental Composition

14 The results of ICP-OES analysis of 46 samples from Sangtarashan are presented in Table 2.

15 These data reveal that all samples consist of binary tin bronze alloys. Tin concentrations

16 vary between 1.78 and $14.5 \mathrm{wt} \%$. It is noteworthy that other metallic elements such as

17 arsenic and lead do not represent major constituents in any of the samples. In fact, all other

18 elements are detected as minor or trace constituents only.

19 The metallurgy of tin bronze emerged in the Early Bronze Age (early third millennium

20 BCE) in western Iran (Luristan) and spread slowly across the Iranian Plateau, as observed

21 from evidence of tin bronze metallurgy during the Late Bronze Age (ca. 2000-1500 BCE)

22 and Early Iron Age in many regions of the Iranian Plateau (Pigott, 2004; Pigott, 2011;

23 Helwing, 2013; Oudbashi, 2019a). Many analytical studies of archaeological materials

24 from the third and second millennium BCE from the Iranian Plateau show that, although

25 evidence of tin bronze in Luristan exists from the Early Bronze Age, the main copper-base

26 metallurgical activity in most of the Plateau region concerns copper and arsenical copper

27 production during that period, sometimes alongside tin bronze.

28 Analysis of several copper-base artefacts dated to the Early and Middle Bronze Age from

29 west of the Iranian Plateau revealed that tin bronze with varying Sn concentrations

30 appeared there. This is observed in artefacts from Early Bronze Age Luristan graveyards 
such as Kalleh Nisar and Bani Surmeh, Susa dated to period IVa (second half of third millennium BCE) and at Godin Tepe III:6 (ca. 2600-2400 BCE), as well as the Bronze Age graveyard of Deh Dumen, south-western Iran (Frame, 2010; Fleming et al., 2005; Malfoy and Menu, 1987; Oudbashi et al., 2016c). It is worth noting that these tin bronze artefacts occurred alongside arsenical copper artefacts, which were common during the Early and Middle Bronze Age of western and south-western Iran.

The earliest evidence of tin bronze in the central Iranian Plateau and southern highlands of Iran emerges at the end of third millennium BCE into the beginning of the second millennium BCE. Earlier examples of tin bronze are very rare in the Early and Middle Bronze Age in central Iran. Nevertheless, a few analysed artefacts from the Bronze Age site Qoli Darvish (middle and late Bronze Age) show that there is no specific system of copper alloying at that time and one low tin bronze artefact illustrates the early use of tin bronze at this site (Nezafati and Stöllner, 2017).

Chemical analysis of numerous copper-base artefacts from the Late Bronze Age sites of Tappeh Bazgir and Shahrak-e Firouzeh in north-eastern Iran revealed that apart from a few low-tin bronze artefacts, all of the analysed artefacts were probably made of copper and an arsenical copper alloy (Lorenz, 2008; Oudbashi et al., 2020). The use of tin bronze is observed in south-central Iran during the early second millennium BCE in the Kaftari phase at Malyan (ca. 2200-1800 BCE), and at Tappeh Yahya IVA (Pigott et al., 2003; Thornton et al., 2002). The analytical studies reveal that tin bronze metallurgy rarely occurred during the Bronze Age, and this is especially true in more eastern regions. Analysis of various artefacts and slags from the Bronze Age sites such as Shahdad, Shahr-i Sokhta and Tappeh Hissar gave little to no evidence of tin bronze metallurgy during the third and second millennium BCE in the north-eastern Iran and in the eastern part of the Lut desert, while arsenical copper (or arsenical bronze) was common at these sites during the Bronze Age (Hauptmann et al., 2003; Meier, 2011; Meier, 2015; Pigott et al., 1982; Thornton 2009). Nonetheless, it is worth noting that a limited number of tin-containing copper artefacts (tin bronzes) is observed among the analysed artefacts from Khenaman or Khinaman, a Bronze Age cemetery located in the Lut Desert, which is related to the Shahdad culture (Curtis, 1988; Maxwell-Hyslop, 1988). In summary, these studies show 
that tin bronze was the main copper-base alloy for metal artefact production on the Iranian

2 Plateau during the Iron Age, but less so during the Bronze Age (Oudbashi, 2019a; 2019b).

3 Figure 5 presents binary diagrams of main elemental constituents of some Iron Age

4 artefacts from different sites of the Iranian Plateau, in which most artefacts are from the

5 Luristan region, except for Haft Tappeh (south-western Iran), Marlik and Sagzabad

6 (northern Iran) and Hasanlu IVB level (north-western Iran). Background information on the

7 data used for comparison in Figure 5 are presented in Table 3. In Figures 5a and 5b, the

8 scatter plot of $\mathrm{Cu}$ versus Sn shows that the majority of the analysed Iron Age artefacts are

9 made of tin bronze and that tin concentrations vary in a wide range in different artefacts

10 from different sites. Figures $5 \mathrm{c}$ and $5 \mathrm{~d}$ present a scatter plot of Sn versus As, the main alloy

11 constituents of prehistoric copper-base artefacts. It is obvious that arsenic did not play an

12 important role in the metallurgy of copper alloys during the Iron Age. Evidence of impure

13 copper and arsenical copper, alongside tin bronze, is found only in some cases, such as

14 Godin Tepe (western Iran), Luristan Bronzes from the Ashmolean museum with no

15 archaeological provenance, Sagzabad and Marlik (northern Iran), Hasanlu (north-eastern

16 Iran) and Haft Tappeh (south-western Iran). Furthermore, the scatter plot presented in

17 Figures 5e and $5 \mathrm{f}(\mathrm{Sn}$ versus $\mathrm{Pb}$ ) shows the limited role of lead as an alloying ingredient in

18 the metallurgy of copper alloys during the Iron Age of the Iranian Plateau. Lead has been

19 measured as a major constituent $(>1 \mathrm{wt} \%)$ in the composition of a few artefacts from the

20 Ashmolean museum (5 artefacts), Haft Tappeh (4 artefacts), War Kabud (7 artefacts) and

21 Baba Jilan (one artefact) and Hasanlu (5 artefacts) only.

22 Figure 6 shows scatter plots of trace elements measured in the majority of the artefacts

23 analysed stemming from Iron Age Iran. From the diagram of Ag versus Ni (Figure 6a), it is

24 clear that the Sangtarashan artefacts exhibit a variable and wide range, partially overlapping

25 with the ranges observed for other artefacts from different sites. The largest overlap can be

26 noted with War Kabud, Baba Jilan and the Ashmolean collection (Luristan Bronzes) and

27 partially with Haft Tappeh and Marlik (Iron Age I), as well as Hasanlu. Furthermore, the

28 diagram indicates that some Sangtarashan artefacts differ strongly from others from a trace

29 element perspective. Figure 6b shows a scatter plot of As versus Sb. Here, it is again

30 obvious that the Sangtarashan artefacts encompass a wide range of compositional 
variability. However, a linear relationship in the As-Sb ratio is visible in the diagram. The

Sangtarashan artefacts partially overlap with many artefacts from different sites, such as Haft Tappeh, Marlik, Baba Jilan, Ashmolean collection, War Kabud, and even with Sagzabad and Hasanlu. It can be derived from both diagrams that, although artefacts from each site/collection overlap with each other to some extent, the Sangtarashan artefacts are strongly variable from a (trace) elemental perspective and overlap with artefacts from most of the different sites/collections. Although this variability is partially visible in artefacts from Marlik and Haft Tappeh as well, it is far more pronounced in the Sangtarashan bronzes, indicating the probable use of various copper sources to manufacture the copper alloy artefacts. In sum, this study of trace elements can be indicative of the possible origin (ore source) of the copper used in the ancient alloys (Pernicka, 2014; Pollard and Bray, 2014), however, in this article we have placed our emphasis on the use lead isotope analysis in an effort to define the provenance of the copper alloy artefacts analysed and presented herein.

\section{Lead Isotopic Analysis}

The lead isotope ratios for the Sangtarashan samples, presented in Table 4, vary between 18.051 and 18.904 for ${ }^{206} \mathrm{~Pb} /{ }^{204} \mathrm{~Pb}, 15.121$ and 15.716 for ${ }^{207} \mathrm{~Pb} /{ }^{204} \mathrm{~Pb}$, and 37.472 and 39.004 for ${ }^{208} \mathrm{~Pb} /{ }^{204} \mathrm{~Pb}$. As illustrated in Figure 7, the lead isotope ratios in the Sangtarashan samples follow a linear trend line, apart from three samples which deviate substantially from the trend line in both the ${ }^{206} \mathrm{~Pb} /{ }^{204} \mathrm{~Pb}$ versus ${ }^{207} \mathrm{~Pb} /{ }^{204} \mathrm{~Pb}$ and ${ }^{206} \mathrm{~Pb} /{ }^{204} \mathrm{~Pb}$ versus ${ }^{208} \mathrm{~Pb} /{ }^{204} \mathrm{~Pb}$ scatter plots (samples ST-06, ST-10 and ST-34).

The lead isotope ratio data available for archaeological objects and metallurgical materials from prehistoric sites in Iran are limited and only some data are available for comparison (see Table 5 for further information). It is worth noting that lead isotope ratios used for comparative studies are from a range of sites across the Iranian Plateau from late Chalcolithic/Bronze Age to Iron Ages. Furthermore, lead isotope ratio data for Iranian ore deposits (ancient and modern) are also limited. Nevertheless, the data available provide a useful comparison to the lead isotope ratios obtained for the Sangtarashan bronzes, as presented in Figure 8. The scatter plots are presented in three formats: full isotopic range 
1 (Figures $8 \mathrm{a}$ and 8b), reduced range of archaeological objects (e.g., copper alloy artefacts,

2 slag and matte) (Figures 8c and 8d) and reduced range of ore deposits (Figures $8 \mathrm{e}$ and $8 \mathrm{f}$ ) in

3 comparison with Sangtarashan lead isotope ratio data. Figures 8a and 8b illustrate that,

4 apart from some cases, the lead isotope ratios of the majority of objects and ores are in a

5 similar range and plot along the same trend line. It is noteworthy that the three outliers from

6 Sangtarashan have lead isotope ratios not previously observed for Iranian objects or ore

7 deposits.

8 Plots of ${ }^{206} \mathrm{~Pb} /{ }^{204} \mathrm{~Pb}$ versus ${ }^{207} \mathrm{~Pb} /{ }^{204} \mathrm{~Pb}$ (reduced to a range of 17.8 to 19.4 for ${ }^{206} \mathrm{~Pb} /{ }^{204} \mathrm{~Pb}$

9 and of 15.5 to 16 for ${ }^{207} \mathrm{~Pb} /{ }^{204} \mathrm{~Pb}$, respectively, as presented in Figures $8 \mathrm{c}$ and Figure $8 \mathrm{e}$ )

10 and ${ }^{208} \mathrm{~Pb} /{ }^{204} \mathrm{~Pb}$ (reduced to a range of 38 to 39.4, as presented in Figures $8 \mathrm{~d}$ and $8 \mathrm{f}$ ), reveal

11 two interesting aspects. First, the majority of samples (both archaeological objects and ores)

12 plot on a broad trend line, and second, the distribution for the Sangtarashan samples is

13 almost as wide as the entire distribution observed for objects from different areas overall,

14 and wider than most individual groups previously characterised. The lead isotope ratios for

15 objects from Arisman (second half of fourth millennium and beginning of third millennium

16 BCE) and sites in the Pusht-i Kuh region equally exhibit a wide range, similar to the

17 Sangtarashan objects. The lead isotope ratios for five samples from Arisman and two

18 samples from the Pusht-i Kuh deviate more strongly from the others of these groups. This

19 is also visible for one sample from Tappeh Sialk. The lead isotope ratios of Sangtarashan

20 artefacts agree well with some of the other data, especially for the Pusht-i Kuh region, the

21 Louvre collection, Qoli Davrish, Tappeh Sarm, Shahr-i Sokhta, etc. However, there is no

22 complete overlap between the data for the Sangtarashan artefacts and those from other

23 archaeological sites, with part of the data being different, for instance, when comparing

24 samples from Arisman, the Pusht-i Kuh and Shahr-i Sokhta.

25 By comparing lead isotope ratios for ore deposits to those for Sangtarashan artefacts

26 (reduced range), it becomes clear that a significant number of samples from Sangtarashan

27 show relatively poor agreement with the known lead isotope ratios of Iranian copper ores.

28 The western ore deposits in the spread along the Astaneh-Sarband area are the nearest

29 copper sources to Luristan that may have been used in prehistory based on evidence

30 observed from the copper-tin ore deposits at Deh Hosein (Nezafati, 2006). There is a partial 
1 (but limited) overlap between lead isotope ratios for some samples from Sangtarashan and

2 Deh Hosein deposits, as well as with those for copper ore sources from Astaneh.

3 Furthermore, the Sangtarashan lead isotope ratios partially overlap with those for copper

4 ore sources located further away in central Iran, such as ore deposits in Anarak, Karkas and

5 Veshnaveh, Kerman (south-central Iran) and even with eastern ore deposits located in the

6 Lut blocks (Pernicka et al., 2011; Nezafati and Stöllner, 2017; Shafiei, 2010; Hauptmann et

7 al., 2003). However, none of the lead isotope ratio data for these deposits individually

8 follows the trend line observed for the Sangtarashan artefacts.

9 Finally, it is important to highlight that three samples from Sangtarashan have completely

10 different lead isotope ratios, showing no overlap with any data for archaeological objects or

11 ore deposits available to the authors. Comparable published lead isotope ratios are very rare

12 not only for Iranian deposits, but exist for others much further afield (Killick et al., 2020),

13 including a few Cenozoic and Mesozoic lead ores from China (Hsu and Sabatini, 2019) and

14 a Palaeozoic azurite/malachite deposit from Asturias, Spain (Huelga-Suarez et al., 2014).

15 These instances do not represent convincing source areas, and the lead isotope ratios for

16 these three artefacts remain to be explained.

\section{Luristan Bronzes: Technology and Provenance}

19 Copper-base metallurgy during the Iron Age in Luristan (western Iran) can be considered

20 primarily a tin bronze metallurgy, including the manufacture of various ritual artefacts with

21 different shaping methods, such as casting and thermo-mechanical processes. Although this

22 seems to be the commonplace metallurgical process for this time period, some interesting

23 aspects can be highlighted based on the analytical studies presented here and in previous

24 research. One of the important aspects of tin bronze metallurgy in Luristan is that

25 manufacturing artefacts with a binary alloy is the main metallurgical process and other

26 alloying or metallic elements play little or no important role in this technology. In fact,

27 although tin bronze emerged and slowly spread during the Bronze Age, it was selected as

28 the main copper-base alloy by ancient Iranian metalworkers in the Iron Age for producing

29 routine and ritual artefacts. Of course, it is worth noting that (impure) copper and arsenical

30 copper are also observed in some archaeological sites as main metals for producing 
artefacts during the Iron Age, such as at Marlik, Haft Tappeh and Sagzabad (Oudbashi and Hessari, 2017; Oudbashi et al., 2019; Oudbashi and Mishmastnehi, 2020; Oudbashi et al., in press; Vatandoost-Haghighi, 1977). However, this is not observed among the Luristan Bronzes. The results of elemental analysis of different collections from the Luristan Bronzes (see Table 3) reveal that among the 164 artefacts belonging to the archaeological sites (War Kabud, Bard-i Bal, Godin Tepe, Sangtarashan and Baba Jilan), as well as museum collections (Ashmolean and Iran National Museum), only 3 artefacts - from the Ashmolean collections - and 5 artefacts from Iron Age of Godin Tepe have low amounts of tin. Furthermore, arsenic has been measured as a major constituent ( $>1 \mathrm{wt} . \%)$ only in a few artefacts from archeological sites, including War Kabud (4 artefacts), Ashmolean collections (4 artefacts), Godin Tepe (6 artefacts), Baba Jilan (2 artefacts), Marlik (4 artefacts), Haft Tappeh (2 artefacts), Sagzabad (one artefacts) and Hasanlu (2 artefacts). Another interesting aspect of tin bronze metallurgy in Luristan is the variable tin content in the artefacts. Based on previously published works, it has been suggested that the prehistoric tin bronze artefacts from the Bronze Age and Iron Age (Iron Age tin bronzes from Luristan) were produced using an uncontrolled (or uncontrollable) alloying process (Oudbashi et al., 2016a; Oudbashi and Hessari, 2017; Oudbashi and Hasanpour, 2018). In literature, different procedures to produce tin bronze alloy in the ancient time have been suggested (Pigott 2004; Rovira et al., 2009; Valério et al., 2013; Murillo-Barroso et al., 2010; Erb-Satullo et al., 2015; Nezafati 2006; Figueiredo et al., 2010; Berger et al., 2019; Farci et al., 2017, Rademakers and Farci 2018; Rademakers et al., 2018):

- co-smelting of copper and tin ores;

- cementation of metallic copper with cassiterite;

- the use of a complex Sn-bearing copper ore for the smelting of copper;

- metal recycling or re-melting of broken metal pieces;

- and direct melting of copper and tin metal together in the crucible. Apart from the final method that may have allowed ancient metalworkers to control the $\mathrm{Cu} / \mathrm{Sn}$ ratio precisely in the final products, it may have been relatively difficult for metalworkers to control the tin content in the final product (artefact/ingot). However, the direct alloying of metallic copper and tin appears to have been unlikely in Luristan (see 
1 further below). This is in contrast with the ancient cuneiform texts from Mesopotamia, in

2 which recipes for the constant proportion of $\mathrm{Cu} / \mathrm{Sn}$ for groups of artefacts from a

3 typological/functional viewpoint are described (Potts 1997; Joannes 1997; Helwing 2009).

4 However, the results of analytical studies on Mesopotamian copper-base artefacts show that

5 proportional control is not commonplace and an uncontrolled alloying process for tin

6 bronze production appears to have been used for the Mesopotamian artefacts during the

7 same period (Hauptmann and Pernicka, 2004). In fact, it can be assumed that the ancient

8 writers may well have referred to the tin oxide (cassiterite) and copper ores (sulphidic or

9 oxidic) instead of metallic coper and tin (Oudbashi and Hasanpour, 2018; Oudbashi et al., 10 2019).

11 It is important to note that all artefacts from Sangtarashan analysed are vessels (or vessel

12 accessories such as pins, handles and spouts) and tin concentrations vary among the

13 samples from 1.78 to $14.5 \mathrm{wt} \%$, showing no correlation between tin concentration and

14 artefacts typology. This variability was observed previously in other copper-base artefacts

15 from prehistoric Iran, including Marlik and Deh Dumen (Oudbashi and Hessari, 2017;

16 Oudbashi et al., 2016c), and particularly in vessels from War Kabud and Sangtarashan

17 (Oudbashi, 2019b).

18 For the artefacts presented in this study, the variability in tin concentrations can be

19 highlighted for vessels from which multiple samples were taken. Examples such as ST.02-

20 10, ST.10-10 and ST.20-10 deonstrate differences in tin concentrations of up to 7 wt $\%$.

21 These differences are accompanied by distinct lead isotope ratios for the different parts,

22 suggesting that these vessels are either composite artefacts, combining different pieces of

23 tin bronze, or some of the pieces analysed may not belong to the same vessel. In contrast,

24 parts from other vessels, such as ST-285, have more homogeneous tin concentrations,

25 despite having distinct lead isotope ratios. Finally, some vessels illustrate the use of the

26 same bronze composition for different parts of the vessel. For example, the same metal

27 batch was used for the vessel body and one shield pin in ST-KH, while another shield pin

28 from the same vessel was made from a distinct tin bronze: this may indicate the flexible use

29 of different raw materials in the manufacture of a single vessel and/or its repair over time.

30 Similarly, lead isotope ratios for the vessel body and edge fragments from ST.04-10 and 
1 ST.08-10 are indistinguishable, although minor variations in tin concentrations can be 2 noted

3 Furthermore, the elemental analysis of the artefacts of Sangtarashan presents a wide range

4 of compositional properties with apparent similarities with different groups of artefacts

5 from other archaeological sites. In fact, the majority of Sangtarashan bronzes are similar to

6 artefacts from Luristan (such as War Kabud and unprovenanced artefacts), while some

7 samples are comparable to artefacts from non-Luristan sites such as Sagzabad or Marlik in

8 northern Iran, from an elemental composition viewpoint (see Figure 6).

9 Accordingly, it can be suggested from the available alloy composition data for Luristan (as

10 well as other Iron Age sites in Iran) that Luristan metalworkers did not systematically

11 control tin concentrations in the final products: they may not have been able to do so given

12 the raw materials and technological knowledge available to them, or were not interested in

13 doing so, possibly due, in part, to the ritual function of the Luristan Bronzes. Adding less than about $15 \mathrm{wt} \%$ tin to copper to make binary alloy leads to a material with physical properties, colour, in particular, that are not strongly but partially influenced by the tin concentration, although the change in these properties increases at higher tin

17 concentrations, as in the decorative artefacts manufactured from high-tin bronzes (Scott 2010; Meeks 1993a; Meeks 1993b). However, it is possible that the Luristan craftspeople may have varied the tin concentrations intentionally to obtain a variety of properties, such as some variable colour and workability, which may have been of technical, as well as of

21 ritual interest (e.g., Mödlinger et al., 2017; Radivojević et al., 2018). Consequently, the

22 Luristan metalworkers didn't systematically control the alloying process which lead to the

23 production of tin bronze artefacts with variable tin contents, perhaps because it was not

24 possible to do so or perhaps because such a treatment was of lesser importance to them.

25 With regard to the lead isotope ratio distribution of the Sangtarashan artefacts, the data for 26 nearly all samples fall along a wide trend line, and only three samples show divergent lead 27 isotope ratios (samples ST-06, ST-10 and ST-34). These are the edge of artefacts ST.03-10, 28 the vessel base from artefacts ST.06-10 and the body of a large handled kettle (sample 29 ST.22-11), respectively. Interestingly, the elemental composition of these three samples 30 doesn't appear distinct from the other Sangtarashan artefacts. The wide distribution of 
1 Sangtarashan lead isotope ratios is most likely indicative of the use of different copper ore

2 deposits to obtain copper metal. The comparative analysis of the lead isotope ratios also

3 indicates similarity with numerous artefacts and ore deposits from different regions on the

4 Iranian Plateau.

5 Comparison with lead isotope data from Bronze and Iron Age objects from different

6 locations from Iran revealed that some Sangtarashan artefacts are consistent with artefacts

7 from western Iran (Luristan in particular), while strong similarity is observed as well with

8 some objects from archaeological sites located further away in central and eastern Iran,

9 such as Tappeh Sialk, Arisman, Tappeh Sarm and Qoli Darvish, and even further away at

10 Shahr-i Sokhta.

11 The lead isotope ratios of several ore deposits from different regions of Iran are partially

12 consistent with those of the Sangtarashan bronzes. In fact, it is not possible to attribute the

13 Sangtarashan artefacts to one or more specific ore deposits from a lead isotope ratio

14 perspective. However, some artefacts of the collection analysed are consistent with ore

15 deposits close to the Luristan region and located in the Astaneh-Sarband area (e.g., Deh

16 Hosein and Astaneh), while some other samples are consistent with lead isotope ratios of

17 ore deposits that are located further away from the Luristan region in central Iran (Karkas

18 and Veshnaveh), as well as in the Anarak region on the central Iranian Plateau (Pernicka et

19 al., 2011; Nezafati and Stöllner, 2017; Shafiei, 2010; Hauptmann et al., 2003). Some are

20 even weakly consistent with ore deposits located very far away in the eastern part of the

21 Plateau located in the Lut block. It is worth noting that the ore deposits used for comparison

22 include both sulphidic and oxidic copper ores (see Table 5). While a partial overlap exists

23 between these different ore deposits and the Sangtarashan artefacts in terms of lead isotope

24 ratios, insufficient trace element data is available to validate them further as possible source

25 candidates. An interesting matter is the presence of tin ores (cassiterite) and high tin

26 concentrations in copper ores of the Astaneh-Sarband area (Deh Hosein and Nezam Abad),

27 which has been identified as a potential source area for direct production of tin bronze

28 during prehistoric times in Iran (Nezafati, 2006).

29 During the last decade, the Astaneh-Sarband area (Sanandaj-Sirjan metamorphic belt), and

30 in particular its Deh Hosein ancient copper mines, have been introduced as a potential ore 
deposit used for tin bronze production in the Bronze Age and Iron Age of Luristan,

2 presumably during the second and first millennium BCE (Nezafati, 2006: 2, Fig. 1.1;

3 Nezafati et al., 2006). The ancient mining sites at Deh Hosein are located about $45 \mathrm{~km}$ from

4 Arak city, the eastern part of central Zagros on the north-eastern border of ancient Luristan.

5 Numerous ellipsoidal open depressions from ancient mining activities have been

6 documented, distributed over an area of $27 \mathrm{~km}^{2}$. Analytical studies suggest that it was may

7 have been in use from the $3^{\text {rd }}$ millennium BCE onwards as a major supplier of tin (bronze)

8 for Iran and Mesopotamia, as well as regions further west (Nezafati et al., 2006; Nezafati et

9 al., 2011). It is worth noting that ancient cuneiform texts mention "tin from the East" of

10 Mesopotamia, that may possibly be matched with the Deh Hosein mines (Muhly, 1973;

11 Moorey, 1994; Pigott 2011: 284-285; Weeks, 1999; 2004). Its proximity to Luristan and the

12 presence of complex copper-tin ores at Deh Hosein, as well as the matching lead isotope

13 ratios of some (especially Bronze Age) Luristan artefacts with those of Deh Hosein ores,

14 have argued for it as one of the main known copper-tin ore deposits used in prehistoric

15 times on the Iranian Plateau. The specific elemental composition of the (Cu-Sn-W-Au) Deh

16 Hosein ores presents the possibility that the direct smelting of complex copper-tin ores was

17 an important alloying method for tin bronze production from Deh Hosein ores

18 (Momenzadeh, 2004; Nezafati, 2006; Pigott 2021). However, Deh Hosein has yet to yield

19 any evidence of prehistoric copper smelting activity. Nevertheless, the lead isotope ratios of

20 tin bronze artefacts from Sangtarashan presented here revealed only a partial overlap with

21 those of the Astaneh-Nezam Abad area (especially Deh Hosein), while the lead isotope

22 ratio data for a significant number of the Sangtarashan artefacts show little consistency with

23 the signature of the ore deposits in this area. It may be suggested, therefore, that the

24 Astaneh-Sarband ore deposits may have been used during the Iron Age as a resource for tin

25 bronze production in Luristan, but not exclusively.

26 The elemental and lead isotopic analyses of the Sangtarashan bronzes show that it is not

27 possible to identify one specific ore deposit or region as the source of copper for tin bronze

28 metallurgy in the Iron Age of Luristan. No evidence of smelting or metal working has been

29 discovered in Luristan yet and it is not clear as yet where the Luristan Bronzes were

30 produced. From an archaeological perspective, the Luristan Bronzes show a specific artistic 
style, but the analytical data show that they were most likely produced from a variety of ore sources, and possibly in different workshops. Accordingly, the following hypotheses can be suggested:

1. The Luristan Bronzes are ritual/funerary artefacts that have been produced in different regions using local ore deposits and were exported from / transported to Luristan to be placed in graves or sanctuaries.

2. The copper (and tin) ores have been imported from different regions of the Iranian Plateau (or even elsewhere) and smelted in the local workshops in Luristan and then the ingots in copper and tin were used to manufacture the Luristan Bronzes.

3. The metallic raw materials (possibly including tin bronze ingots) were produced elsewhere and then brought to Luristan to produce artefacts in the Luristan style. The first is less likely because of the unique and homogeneous artistic style of the Luristan Bronzes, and it is difficult to imagine the production of highly similar artefacts in different regions on the Plateau or further afield. However, no local smelting and/or metal working workshops have there been located in Luristan yet, although it is possible that future archaeological and field studies may yield new evidence in this regard. The lack of (hitherto known) local metallurgical activity has been ascribed to the difficult topography of the Luristan region (with high mountains and deep valleys), possibly hindering the establishment of large-scale production during prehistory (Begemann et al., 2008; Moorey, 1969). Nevertheless, the results of the analytical studies show that the Luristan Bronzes technology cannot be interpreted as an entirely local industry, as the raw materials used (or, less probably, the final artefacts) have been imported from different regions of Iran. In fact, this region was very important (or sacred) during the Iron Age and people from different regions may have presented these artefacts as gifts in the graves/sanctuaries. It is possible that these artefacts were transported by ancient nomadic peoples that may have been responsible for the formation of Luristan culture during the Iron Age. These artefacts could have been manufactured by them elsewhere and then aggregated in the sacred places in Luristan. This is already an old hypothesis developed by archaeologists as early as the last century due to absence of Iron Age settlement evidence in Luristan (e.g., Godard 1931; see 
1 also Overlaet, 2004; Porada, 1964). Recent excavation evidence, however, argues against

2 this hypothesis.

3 Based on currently available evidence, it is thus most likely that raw metals, copper and tin,

4 were brought to Luristan for the production of these vessels. Apart from copper, tin and/or

5 tin bronze ingots, the possibility of recycled bronze from different regions in Iran being

6 used for the production of these bronzes in Luristan could equally fit the picture painted by

7 the new data presented here.

8 A notable possibility is that tin may have been imported to Luristan from the southern

9 lowlands. The Elamite civilization was located in southern and south-eastern Luristan and

10 provided a trade route between the Mesopotamian lowlands and the Iranian Plateau during

11 third to first millennium BCE. One avenue of further research is the potential interaction of

12 Elam with Luristan as arguments have been made for the potential control of the tin trade

13 'from the East" by the Elamites (Pigott, 2021; Helwing, 2009).

14 Overall, these data suggest that the Luristan Bronzes found at Sangtarashan were produced

15 following a variety of tin bronze recipes and a wide range of raw materials. The variability

16 in alloy compositions may be a reflection of these different raw materials (including bronze

17 ingots) arriving in Luristan and being used to produce the artefacts, without any systematic

18 selection by the Luristan metalworkers. Variability between different workshops may have

19 existed as well. To elucidate this further, future study of production remains will be

20 essential. Regardless, the results presented here shed a new light on the provisioning

21 systems underlying the Luristan Bronzes, which were of key importance in the technology,

22 religion and trade underway on the Iranian Plateau during the Iron Age.

\section{Conclusion}

25 This paper has presented the results of an extensive archaeometallurgical study on Luristan

26 Bronzes dating back to the first millennium BCE and excavated from the Sangtarashan

27 sanctuary located in the Pish-i Kuh region of Luristan (western Iran). This study aimed to

28 investigate the alloying technologies and provenance of the raw materials used, based on

29 elemental and lead isotopic analysis of a series of copper-base artefacts from the site along

30 with a broad-based comparison with available data from previous studies on copper-base 
artefacts and copper ore deposits from the Iranian Plateau. The results of elemental analysis showed that the Sangtarashan artefacts are made of tin bronze alloys with variable tin concentrations, while other metallic constituents are only visible as impurities in the composition of these artefacts. Such variation in the tin content has been observed repeatedly for prehistoric tin bronze artefacts of Iran from the third to first millennia BCE. Other materials such as arsenical copper and impure copper were used during the Bronze Age and Iron Age in some regions of Iran as well, although during the Iron Age (ca. 1500$550 \mathrm{BCE}$ ). tin bronze was the main copper-base technology. The provenance studies on the Sangtarashan tin bronze artefacts have shown that this collection -as well as other artefacts attributed to the Luristan Bronzes- may not have been produced by using a specific ore deposit and it is more probable that these artefacts have been produced from different copper (ore) sources from widespread ore deposits across Iran (and presumably neighbouring regions). This production may have relied on the import of ores from different regions or, more likely, the trading of raw metals (including copper and tin ores, but possibly also tin bronze ingots and recycled tin bronzes) from other regions to Luristan to manufacture the individual artefacts by Luristan metalworkers. The variability in alloy compositions for similar artefacts (for example the Sangtarashan vessels) may be a reflection of using different raw materials (including copper and tin ores) arriving in Luristan to produce these artefacts, or perhaps the weak control of tin concentrations during the alloying process by the Luristan metalworkers. It is worth noting that it is not possible to specify one or more places as metallurgical workshops for manufacturing the Luristan Bronzes due to a lack of archaeological data on this subject, but it is quite possible that they have been manufactured by peoples who lived in Luristan, including perhaps ancient nomads who migrated to Luristan during the Iron Age, using ores and raw materials from different regions. Given the importance of the Elamite empire (not civilization) and its widespread influence in south-western Iran and beyond, tin in particular may have reached Luristan via Elam as the empire lies immediately to the south and appears to have been actively involved in the tin trade. Finally, the present study clarified more details about the technology and provenance of the Luristan Bronzes, especially by showing the use of widespread copper sources on the Plateau apparently used to produce these the 
1 Sangtarashan and other related Luristan Bronzes. Nevertheless, it is necessary to expand

2 archaeometallurgical and archaeological research on the Luristan Bronzes to obtain a

3 clearer picture of their copper-base metallurgy during the prehistoric period of western Iran.

4

5 Acknowledgements

6 We are grateful to Kris Latruwe for performing quantitative $\mathrm{Pb}$ determination using ICP-

$7 \quad \mathrm{MS}$ and $\mathrm{Pb}$ isotopic analysis using MC-ICP-MS at Ghent University, and Elvira Vassilieva

8 for chemical analyses performed at KU Leuven. This research was funded by the KU

9 Leuven Centre for Archaeological Sciences (CAS). We are also thankful to Prof. Vincent

10 C. Pigott from University of Pennsylvania for reading the manuscript and providing useful

11 scientific comments and corrections on the paper. The Flemish Research Foundation

12 (FWO) is also acknowledged for providing the funding for the acquisition of the MC-ICP-

13 MS instrumentation (ZW15-02 - G0H6216N). Also we are tankful from Deputy of

14 Research and Technology of Art University of Isfahan and Iranian Center for

15 Archaeological Research (ICAR) for support this research project. We are very grateful to

16 the two anonymous reviewers for their very constructive feedback which has helped to

17 improve this manuscript.

\section{References}

20 Begemann, F., Haerinck, E., Overlaet, B., Schmitt-Strecker, S., Tallon, F., 2008. An

21 Archaeo-Metallurgical Study of the Early and Middle Bronze Age in Luristan, Iran. Iran.

22 Antiq. XLIII, 2-66.

23 Berger, D., Brugmann, G., Pernicka, E., 2019. On Smelting Cassiterite in Geological and

24 Archaeological Samples: Preparation and Implications for Provenance Studies on Metal

25 Artefacts with Tin Isotopes. Archaeol. Anthrop. Sci. 11, 293-319.

26 Calmeyer, P., 1969. Datierbare Bronzen aus Luristan und Kirmanshah, de Gruyter, Berlin.

27 Chegini, N.N., Momenzadeh, M., Parzinger, H., Pernicka, E., Stöllner, T., Vatandoust, R.,

28 Weisgerber, G., 2000. Preliminary Report on Archaeometallurgical Investigations around

29 Prehistoric Site of Arisman Near Kashan, Western Central Iran. Archäologische

30 Mitteilungen aus Iran und Turan 32, 281-318. 
1 Curtis, J., 1988. A Reconsideration of the Cemetery at Khinaman, Southeast Iran. Iran.

2 Antiq. XXIII, 97-124.

3 De Muynck, D., Cloquet, C., Vanhaecke, F., 2008. Development of a New Method for Pb

4 Isotopic Analysis of Archaeological Artefacts using Single-Collector ICP-Dynamic

5 Reaction Cell-MS. J. Anal. Ato. Spectrom. 23, 62-71.

6 Erb-Satullo, N.L., Gilmour B.J.J., Khakhutaishvili, N., 2015. Crucible Technologies in the

7 Late Bronze Early Iron Age South Caucasus: Copper Processing, Tin Bronze Production,

8 and the Possibility of Local Tin Ores. J. Archaeol. Sci. 61, 260-276.

9 Farci, C., Martinon-Torres, M., Gonzalez Alvarez, D., 2017. Bronze Production in the Iron

10 Age of the Iberian Peninsula: The Case of El Castru, Vigana (Asturias, NW Spain). J.

11 Archaeol. Sci. Rep. 11, 338-351.

12 Figueiredo, E., Silva, R.J.C., Senna-Martinez, S.C., Araujo, M.F., Fernandes, F.M.B., Ines

13 Vaz, J.L., 2010. Smelting and recycling evidences from the Late Bronze age habitat site of

14 Baioes (Viseu, Portugal). J. Archaeol. Sci. 37, 1623-1634.

15 Fleming, S.J., Nash S.K., Swann, C.P., 2011. The Archaeometallurgy of the Period IVB

16 Bronzes at Hasanlu, in: Maude de Schauensee (Ed.), Peoples and Crafts in Period IVB at

17 Hasanlu, Iran, University of Pennsylvania Museum of Archaeology and Anthropology,

18 Philadelphia, pp. 102-134.

19 Fleming, S.J., Pigott, V.C., Swann, C.P., Nash, S.K., Haerinck, E., Overlaet, B., 2006. The

20 Archaeometallurgy of War Kabud, Western Iran. Iran. Antiq. XLI, 31-57.

21 Fleming, S.J., Pigott, V.C., Swann, C.P., Nash, S.K., 2005. Bronze in Luristan: Preliminary

22 Analytical Evidence from Copper/Bronze Artifacts Excavated by the Belgian Mission in

23 Iran. Iran. Antiq. XL, 35-64.

24 Frame, L.D., 2010. Metallurgical Investigations at Godin Tepe, Iran, Part I: The Metal

25 Finds. J. Archaeol. Sci. 37, 1700-1715.

26 Galer, S.J.G., Abouchami, W., 1998. Practical Application of Lead Triple Spiking for

27 Correction of Instrument Mass Discrimination. Mineral. Mag. 62, 491-492.

28 Godard, A., 1931. Les Bronzes du Luristan, Les Editions G. Van Oest, Paris. 
1 Goff, C., 1968. Luristan in the First Half of the First Millennium BC., a Preliminary Report

2 on the First Season's Excavations at Baba Jan, and Associated Surveys in the Eastern Pish-i

3 Kuh. Iran 6, 105-134.

4 Haerinck, E., 2009. Louis Vanden Berghe, Encyclopaedia Iranica Online, Originally

5 Published: July 20, 2009, https://iranicaonline.org/articles/vanden-berghe-louis

6 Haerinck, E., Overlaet, B., Jaffar-Mohammadi, Z., 2004. Finds from Khatunban B -

7 Badavar Valley (Luristan) in the Iran Bastan Museum. Iran. Antiq. 39, 105-168.

8 Haerinck, E., Overlaet, B., 2004a. The Chronology of the Pusht-i Kuh, Luristan, Results of

9 the Belgian Archaeological Mission in Iran, in: From Handaxe to Khan, Essays Presented

10 to Peder Mortensen on the Occasion of his 70th Birthday, Aarhus, 119-135.

11 Haerinck, E., Overlaet, B., 2004b. The Iron Age III Graveyard at War Kabud, Pusht-i Kuh,

12 Luristan, Luristan excavation documents 5, Acta Iranica 42, Leuven.

13 Haerinck, E., Overlaet, B., 1999. Djub-i Gauhar and Gul Khanan Murdah: Iron Age III

14 Graveyards in the Aivan Plain, Luristan excavation documents 3, Acta Iranica 36, Leuven.

15 Haerinck, E., Overlaet, B., 1998. Chamahzi Mumah: An Iron Age III Graveyard, Luristan

16 excavation documents 2, Acta Iranica 33, Leuven.

17 Hasanpur, A., Malekzadeh, M., 2019. Sangtarashan after Six Seasons of Archaeological

18 Excavations, in: Hassanzadeh, Y., Vahdati, A.A., Karimi, Z. (Eds.), Proceedings of the

19 International Conference on the Iron Age in Western Iran and Neighbouring Regions, Vol.

20 1, RICHT, National Museum of Iran and Kurdistan ICHHTO Publications, Tehran, pp.

21 151-174 (in Persian).

22 Hasanpur, A., Hashemi, Z., Overlaet, B., 2015. The Baba Jilan Graveyard near Nurabad,

23 Pish-i Kuh, Luristan. Iran. Antiq. 50, 171-212.

24 Hashemi, Z. Malekzadeh, M., Hasanpour, A., 2021. Sangtarashan: un Lieu Rituel à l'âge du

25 Fer au Pish Kuh du Luristan, Luristan Excavation Documents, Acta Iranica, Peeters,

26 Leuven.

27 Hauptmann, H., Pernicka, E., (Eds.) 2004. Die Metallindustrie Mesopotamiens von den

28 Anfangen bis zum 2. Jahrtausend v. Chr. Orient - Archäologie Band 3. Marie Leidorf, 29 Rahden. 
1 Hauptmann, A., Rehren, T., Schmitt-Strecker, S., 2003. Early Bronze Age Copper

2 Metallurgy at Shahr-i Sokhta (Iran), Reconsidered, in: Stöllner, T., Körlin, G., Steffens, G.,

3 Cierny, J., (Eds.), Man and Mining - Mensch und Bergbau. Der Anschnitt, Beiheft, Vol 16.

4 Deutsches Berbgau-Museum, Bochum, pp. 197-213.

5 Helwing, B., 2013. Early Metallurgy in Iran — an Innovative Region as Seen from the

6 Inside, in: Burmeister, S., Hansen, S., Kunst, M., Müller- Scheeßel, N., (Eds), Metal

7 Matters: Innovative Technologies and Social Change in Prehistory and Antiquity,

8 Menschen-Kulturen-Traditionen, Forschungs cluster 2, band 12. Deutsches

9 Archäologisches Institut, Berlin, pp. 105-136.

10 Helwing, B., 2009. Rethinking the Tin Mountains: Patterns of Usage and Circulation of Tin

11 in Greater Iran from the 4th to the 1st millennium BC. TUBA-AR 12, 209-221.

12 Hsu, Y.-K., Sabatini, B.J., 2019. A Geochemical Characterization of Lead Ores in China:

13 An Isotope Database for Provenancing Archaeological Materials. PLOS One 14, e0215973.

14 Huelga-Suarez, G., Moldovan, M., Suárez Fernández, M., Ángel de Blas Cortina, M.,

15 García Alonso, J.I., 2014. Defining the Lead Isotopic Fingerprint of Copper Ores from

16 North-West Spain: The El Milagro Mine (Asturias). Archaeometry 56, 88-101.

17 Joannes, F., 1997. Metalle und Metallurgie, A. I. in Mesopotamien. Reallexikon der

18 Assyriologie und vorderasiatischen Archäologie 8, 96-112.

19 Killick, D., Stephens, J., Fenn, T.R., 2020. Geological Constraints on the Use of Lead

20 Isotopes for Provenance in Archaeometallurgy. Archaeometry 62, 86-105.

21 Lorenz, S., 2008. Archäometrische untersuchungen am hortfund von Bazgir, Iran,

22 Diplomarbeit-Magister, Institut für Archämetries, Fakultät für Werkstoffwissenschaft und

23 Werkstofftechnologie, TU Bergakademie Freibreg (Unpublished).

24 Malekzadeh, M., Hasanpur, A., Hashemi, Z., 2018. Bronzes of Luristan in a Non-funerary

25 Context: Sangtarashan, an Iron Age Site in Luristan (Iran), in: Horejs, B., Schwall, C.,

26 Müller, V., Luciani, M., Ritter, M., Giudetti, M., Salisbury, R.B., Höflmayer, F., Bürge, T.,

27 (Eds.), Proceedings of the 10th International Congress on the Archaeology of the Ancient

28 Near East, Vol. 2, Harrassowitz Verlag, Wiesbaden, pp. 577-588.

29 Malekzadeh, M., Hasanpur, A., Hashemi, Z., 2017. Fouilles (2005-2006) à Sangtarashan, 30 Luristan, Iran". Iran. Antiq. 52, 61-158. 
1 Malfoy, J.M., Menu, M., 1987. La Métallurgie du Cuivre à Suse aux IVe et IIIe

2 Millénaires: Analyses en Laboratoire, in: F. Tallon, J.-M. Malfoy (Eds.), Métallurgie

3 Susienne I: 1. De la fondation de Suse au XVIIIe avant J.-C, Paris: Notes et documents des

4 musées de France, Paris.

5 Maxwell-Hyslop, K.R., 1988. A Comment on the Finds from Khinaman. Iran. Antiq.

6 XXIII, 129-138.

7 Meeks, N., 1993a. Patination Phenomenon on Roman and Chinese High-Tin Bronze

8 Mirrors and Other Artefacts, in: La Niece, S., Craddock, P., (Eds.), Metal Plating and

9 Patination, Cultural, Technical and Historical Developments, Butterworth-Heinemann,

10 Oxford, 63-84.

11 Meeks, N., 1993b. Surface Characterization of Tinned Bronze, High-Tin bronze, Tinned

12 Iron and Arsenical Bronze. in: La Niece, S., Craddock, P., (Eds.), Metal Plating and

13 Patination, Cultural, Technical and Historical Developments, Butterworth-Heinemann,

14 Oxford, 247-275.

15 Meier, D.M.P., 2015. Traces of protohistorical metallurgical activities during the 3rd

16 millennium BCE in East Iran with a special focus on the case of Shahdad in the Dasht-eh

17 Lut (Kerman province). PhD Dissertation, Freie Universität Berlin.

18 Meier, D.M.P., 2011. Preliminary Archaeometallurgical Investigations of Bronze Age

19 Metal Finds from Shahdad and Tepe Yahya. Iranian Journal of Archaeological Studies 1, $20 \quad 25-34$.

21 Momenzadeh, M., 2004. Metallic Mineral Resources of Iran, Mined in Ancient Times: a

22 Brief Review, in: Stöllner, T., Slotta, R., Vatandoust, A., (Eds.), Persia’s ancient splendour, 23 mining, handicraft and archaeology. Deutsches Bergbau-Museum, Bochum, pp. 8-21.

24 Moorey, P.R.S., 1994. Ancient Mesopotamian Materials and Industries, The

25 Archaeological Evidence, Clarendon Press, Oxford.

26 Moorey, P.R.S., 1969. Prehistoric Copper and Bronze Metallurgy in Western Iran (With

27 Special Reference to Lūristān),.Iran 7, 131-153.

28 Moorey, P.R.S., 1964. An Interim Report on Some Analyses of "Luristan Bronzes".

29 Archaeometry 7, 72-79. 
1 Mortazavi, M., Salehi Kkakhki, A., Colozar, M.A., Tala'i, H., 2011. Preliminary

2 Metallurgical Investigation of Copper-Based Artifacts at Tepe Sagzabad in Qazvin Plain,

3 Iran (1500-800 BC). Iranian Journal of Archaeological Studies 1, 49-59.

4 Muhly, J.D., 1973. Copper and Tin, The Distribution of Mineral Resources and the Nature

5 of the Metals Trade in the Bronze Age, The Connecticut Academy of Arts and Sciences,

6 New Haven, Connecticut, pp. 155-536.

7 Murillo-Barroso, M., Pryce, T.O., Bellina, B., Martinón-Torres, M., 2010. Khao Sam Kaeo-

8 an Archaeometallurgical Crossroads for Trans-Asiatic Technological Traditions. J.

9 Archaeol. Sci. 37, 1761-1772.

10 Muscarella, O.W., 1990. Bronzes of Luristan, in: Yarshater, E., (Ed.), Encyclopedia

11 Iranica, Vol. IV, Fasc. 5, pp. 478-483.

12 Muscarella, O.W., 1988a. Bronze and Iron: Ancient Near Eastern Artifacts in the

13 Metropolitan Museum of Art, Metropolitan Museum of Art, New York.

14 Muscarella, O.W., 1988b. The Background to the Luristan Bronzes, in: Curtis, J.,

15 (Ed.), Bronzeworking Centres of Western Asia 1000-539 B.C., London, pp. 177-192.

16 Mödlinger, M., Kuijpers, M.H.G., Braekmans, D., Berger, D., 2017. Quantitative

17 Comparisons of the Color of CuAs, CuSn, CuNi, and CuSb Alloys. J. Archaeol. Sci. 88, $18 \quad 14-23$.

19 Nezafati, N., 2006. Au-Sn-W-Cu-Mineralization in the Astaneh-Sarband Area, West

20 Central Iran, Including a Comparison of the Ores with Ancient Bronze Artifacts from

21 Western Asia, PhD Thesis, Der Eberhard-Karls-Universität Tübingen.

22 Nezafati, N., Stöllner, T., 2017. Economic Geology, Mining Archaeological and

23 Archaeometric Investigations at the Veshnaveh Ancient Copper Mine, Central Iran. Metalla

$24 \quad 23,67-90$

25 Nezafati, N., Pernicka, E., Momenzadeh, M., 2011. Early Tin-Copper Ore from Iran, a

26 Possible Clue for the Enigma of Bronze Age Tin. Anatolian Metal V, Der Anschnitt 24,

$27 \quad 211-230$.

28 Nezafati, N., Pernicka, E., Malek Shahmirzadi, S., 2008. Evidence on the ancient mining

29 and metallurgy at Tappeh Sialk (central Iran), in: Yalçin, Ü., Özbal, H., Paşamehmetoğlu, 
1 A.G., (Eds.), Ancient Mining in Turkey and the Eastern Mediterranean, Atilim University,

2 Ankara, pp. 329-350.

3 Nezafati, N., Pernicka, E., Momenzadeh, M., 2006. Ancient Tin: Old Question and a New

4 Answer. Antiquity 80, 308

5 Oudbashi, O., 2019a. The Bronze Metallurgy in the Iron Age: Tin Bronze Production

6 Tradition during the Iron Age in the Central Zagros, in: Hassanzadeh, Y., Vahdati, A.A.,

7 Karimi, Z. (Eds.), Proceedings of the International Conference on the Iron Age in Western

8 Iran and Neighbouring Regions, Vol. 1, RICHT, National Museum of Iran and Kurdistan

9 ICHHTO Publications, Tehran, pp. 206-219 (in Persian).

10 Oudbashi, O., 2019b. A New Look at an Old Technology: Insights into the Metallurgy of

11 Tin Bronze during the Iron Age of Luristan, in: Baas, P., (Ed.), Proceedings of the XXth

12 International Congress on Ancient Bronzes: Resource, Reconstruction, Representation,

13 Role, Bar Publishing, pp. 91-100.

14 Oudbashi, O., 2018. A Methodological Approach to Estimate Soil Corrosivity for

15 Archaeological Copper Alloy Artefacts. Herit. Sci. 6, 2.

16 Oudbashi, O., Mehofer, M., Bahadori, S., Aliyari, A., Tala'i, H., (in press), The Emergence

17 and Spread of Tin Bronze Alloying in Prehistoric Iran - The LBA Metallurgy in Sagzabad,

18 Northern Iran, in: Proceeding of International Conference Archaeometallurgy in Europe

19 (AIE2019).

20 Oudbashi, O., Mehofer, M., Basafa, H., Tayyari, J., Bahadori, S., 2020. Arsenical Copper

21 and Bronze Metallurgy during Late Bronze Age of North-Eastern Iran: Evidences from

22 Shahrak-e Firouzeh Archaeological Site. Archaeol. Anthropol. Sci. 12, 231.

23 Oudbashi, O., Mishmastnehi, M., 2020. Archaeometallurgy of Copper in the Middle

24 Elamite Period of Southwestern Iran: Analytical Investigation of various Parts of the

25 Copper Production in Haft Tappeh. J. Archaeol. Sci. Rep. 30, 102216.

26 Oudbashi, O., Agha-Aligol, D., Mishmastnehi, M., Barnoos, V., 2019. The Elamite

27 Metalworkers: Multianalytical Study on Copper Objects and Ingots from Second

28 Millennium BC of Southwestern Iran. Archaeol. Anthropol. Sci. 11, 2059-2072. 
1 Oudbashi, O., Hasanpour, A., 2018. Bronze Alloy Production during the Iron Age of

2 Luristan: a Multianalytical Study on Recently Discovered Bronze Objects. Archaeol.

3 Anthropol. Sci. 10, 1443-1458.

4 Oudbashi, O., Hessari, M., 2017. Iron Age Tin Bronze Metallurgy at Marlik, Northern Iran:

5 an Analytical Investigation. Archaeol. Anthropol. Sci. 9, 233-249.

6 Oudbashi, O., Hasanpour, A., Malekzadeh, M., 2016a. The Luristan Bronzes in

7 Sangtarashan: Bronze Technology in Western Iran in the First Millennium BC, in: Giumlia-

8 Mair, A., Mattusch, C. C., (Eds.), Proceedings of the XVIIth International Congress on

9 Ancient Bronzes, Izmir, Autun, Éditions Mergoil, pp. 17-27.

10 Oudbashi, O., Hasanpour, A., Davami, P., 2016b. Investigation on Corrosion Stratigraphy

11 and Morphology in some Iron Age Bronze Alloys Vessels by OM, XRD and SEM-EDS

12 Methods, Appl. Phys. A-Matter. 122, 262.

13 Oudbashi, O., Naseri, R., Malekzadeh, M., 2016c. Technical Studies on the Bronze Age

14 Metal Artefacts from the Graveyard of Deh Dumen, South-Western Iran (Third Millennium 15 BC). Archaeometry 58, 947-965.

16 Oudbashi, O., Davami, P., 2014. Metallography and Microstructure Interpretation of some

17 Archaeological Tin Bronze Vessels from Iran. Mater. Charact. 97, 74-82.

18 Oudbashi, O., Emami, S. M., Malekzadeh, M., Hasanpour A., Davami, P., 2013.

19 Archaeometallurgical Studies on the Bronze Vessels from Sangtarashan, Luristan, W-Iran.

20 Iran. Antiq. XLVIII, 147-171.

21 Overlaet, B., 2011. Čale Ğār (Kāšān Area) and Votives, Favissae and Cave Deposits in pre-

22 Islamic and Islamic Traditions, Archäologische Mitteilungen aus Iran und Turan 43: 11323140.

24 Overlaet, B., 2006. Luristan Bronzes I: The Field Research, in: Yarshater, E., (Ed.)

25 Encyclopaedia Iranica Online.

26 Overlaet, B., 2005. The Chronology of the Iron Age in the Pusht-iKuh, Luristan. Iran.

27 Antiq. XL, 1-33.

28 Overlaet, B., 2004. Luristan Metalwork in the Iron Age, Stöllner, T., Slotta, R., Vatandoust, 29 A., (Eds.), Persia's ancient splendour, mining, handicraft and archaeology. Deutsches 30 Bergbau-Museum, Bochum, pp. 328-338. 
1 Pernicka, E., 2014. Provenance Determination of Archaeological Metal Objects, in: Roberts

2 B.W., Thornton, C.P., (Eds.), Archaeometallurgy in Global Perspective, Methods and

3 Syntheses, Springer, New York, pp. 239-268.

4 Pernicka, E., Adam, K., Böhme, M., Hezarkhani, Z., Nezafati, N., Schreiner, M.,

5 Winterholler, B., Momenzadeh, M., Vatandoust, A., 2011. Archaeometallurgical

6 Researches at Arisman in Central Iran, in: Vatandoust, A., Parzinger, H., Helwing, B.,

7 (Eds.), Early Mining and Metallurgy on the Central Iranian Plateau, Report on the First

8 Five Years of Research of the Joint Iranian-German Research Project, Archäologische

9 Mitteilungen aus Iran und Turan 9, Philipp von Zabern, Mainz, pp. 633-705.

10 Pigott, V.C., 2021. The Acquisition of Tin in Bronze Age Southwest Asia. in: Lyonnet, B.,

11 Dubova, N.A., (Eds.), The World of the Oxus Civilization, Routledge, London, pp. 827-

12861.

13 Pigott, V.C., 2011. Sources of Tin and the Tin Trade in Southwest Asia: Recent Research

14 and its Relevance to Current Understanding, in: Betancourt P.P., Ferrence S.C. (Eds.),

15 Metallurgy: understanding how, learning why, studies in honor of James D. Muhly,

16 Prehistory Monograph 29. INSTAP Academic Press, Philadelphia, pp. 273-291.

17 Pigott, V.C., 2004. On the importance of Iran in the Study of Prehistoric Copper-Base

18 Metallurgy, in: Stöllner, T., Slotta, R., Vatandoust, A., (Eds.), Persia's ancient splendour,

19 mining, handicraft and archaeology. Deutsches Bergbau-Museum, Bochum, pp. 28-43.

20 Pigott, V.C., Rogers, H.C., Nash, S.K., 2003. Archaeometallurgical Investigations at Tal-e

21 Malyan: The Evidence for Tin-Bronze in the Kaftari Phase, in: Miller, N.F., Abdi, K.

22 (Eds.), Yeki Bud, Yeki Nabud: Essays on the archaeology of Iran in honor of William M.

23 Sumner, University of Pennsylvania Museum of Archaeology and Anthropology,

24 Philadelphia, pp. 161-175.

25 Pigott, V.C., Howard, S.M., Epstein, S.M., 1982. Pyrotechnology and Culture Change at

26 Bronze Age Tepe Hissar (Iran), in: Wertime, Th.A., Wertime, S.F. (Eds.), Early

27 Pyrotechnology: the evolution of the first fire-using industries, Smithsonian Institution

28 Press, Washington D.C., pp. 215-236. 
1 Porada, E., 1964. Nomads and Luristan Bronzes: Methods Proposed for a Classification of

2 the Bronzes, in: Mellink, M. J., (Ed.), Dark Ages and Nomads c. 1000 B.C., Istanbul, pp.

3 9-31.

4 Pollard, A.M., Bray, P., 2014. Chemical and Isotopic Studies of Ancient Metals, in:

5 Roberts B.W., Thornton, C.P. (Eds.), Archaeometallurgy in Global Perspective, Methods

6 and Syntheses. Springer, New York, pp. 217-238.

7 Potts, D.T., 1997. Mesopotamian civilization: the material foundations, Cornell University

8 Press, New York.

9 Rademakers, F.W., Farci, C. 2018. Reconstructing Bronze Production Technology from

10 Ancient Crucible Slag: Experimental Perspectives on Tin Oxide Identification. J. Archaeol.

11 Sci. Rep. 18, 343-355.

12 Rademakers, F.W., Rehren, Th., Pusch, E.B., 2018. Bronze Production in Pi-Ramesse:

13 Alloying Technology and Material Use, in: Ben-Yosef, E., (Ed.), Mining for Copper:

14 Essays in Memory of Professor Beno Rothenberg, Tel Aviv: University of Tel Aviv, pp.

$15 \quad 503-525$.

16 Rademakers, F.W., Verly, G., Somaglino, C., Degryse, P., 2020. Geochemical Changes

17 during Egyptian Copper Smelting? An Experimental Approach to the Ayn Soukhna Process

18 and Broader Implications for Archaeometallurgy. J. Archaeol. Sci. 122, 105223.

19 Radivojević, M., Pendić, J., Srejić, A., Korać, M., Davey, C., Benzonelli, A., Martinón-

20 Torres, M., Jovanović, N., Kamberović, Ž., 2018. Experimental Design of the Cu-As-Sn

21 Ternary Colour Diagram. J. Archaeol. Sci. 90, 106-119.

22 Rovira, S., Montero-Ruiz, I., Renzi, M., 2009. Experimental Co-Smelting to Copper-Tin

23 Alloys, in: Kienlin, T.L., Roberts, B., (Eds.), Metals and Societies Studies in Honour of

24 Barbara S. Ottaway, pp. 407-414.

25 Schmidt, E.F., Van Loon, M.N., Curvers, H.H., 1989. The Holmes expeditions to Luristan,

262 Vols., The Oriental Institute of The University of Chicago Publications 108, Chicago.

27 Scott, D.A., 2010. Ancient Metals: Microstructure and Metallurgy, Vol 1. Principles and

28 Practice, Conservation Science Press, Los Angeles. 
1 Shafiei, B., 2010. Lead Isotope Signatures of the Igneous Rocks and Porphyry Copper

2 Deposits from the Kerman Cenozoic Magmatic Arc (SE Iran), and Their Magmatic-

3 Metallogenetic Implications. Ore Geol. Rev. 38, 27-36.

4 Thornton, C.P., 2009. The Chalcolithic and Early Bronze Age Metallurgy of Tepe Hissar,

5 Northeast Iran: A Challenge to the Levantine Paradigm. PhD dissertation, Department of

6 Anthropology, University of Pennsylvania.

7 Thornton, C.P., Lamberg-Karlovsky, C.C., Liezers, M., Young, S.M.M., 2002. On Pins and

8 Needles: Tracing the Evolution of Copper-Base Alloying at Tepe Yahya, Iran, via ICP-MS

9 Analysis of Common-Place Items. J. Archaeol. Sci. 29, 1451-1460.

10 Valério, P., Monge Soares, A.M., Silva, R.J.C., Araújo, M.F., Rebelo, P., Neto, N., Santos,

11 R., Fontes, T., 2013. Bronze Production in Southwestern Iberian Peninsula: the Late

12 Bronze Age Metallurgical Workshop from Entre Águas 5 (Portugal). J. Archaeol. Sci. 40, $13 \quad 439-451$.

14 Vanden Berghe, L., 1987. Les Pratiques Funéraires à l'âge du Fer III au Pusht-i Kuh,

15 Luristan: les Nécropoles žgenre War Kabud. Iran. Antiq. 32, 201-66.

16 Vanden Berghe, L., 1981. Luristan: Vorgeschichtliche Bronzekunst aus Iran, Munich.

17 Vanden Berghe, L., 1971. Excavations in Pusht-i Kuh (Iran) Tombs Provide Evidence on

18 Dating "Typical Luristan Bronzes". Archaeology 24, 263-271.

19 Vatandoost-Haghighi, A., 1977. Aspects of Prehistoric Iranian Copper and Bronze

20 Technology, PhD Thesis. University of London, Institute of Archaeology.

21 Weeks, L., 1999. Lead Isotope Analyses from Tell Abraq, United Arab Emirates: New Data

22 Regarding the 'Tin Problem' in Western Asia. Antiquity 73, 49-64.

23 Weeks, L., 2004. Early Metallurgy of the Persian Gulf, Technology, Trade, and the Bronze

24 Age World, American School of Prehistoric Research Monograph Series, Brill Academic

25 Publishers Inc., Boston, Leiden. 


\section{Figure Captions}

2 Figure 1- a) Map of Iran indicating the location of the Sangtarashan sanctuary in western

3 Iran, as well as major archaeological sites and ore deposits mentioned in the paper, b)

4 detailed map of Luristan and archaeological sites mentioned in the text.

5 Figure 2- a) Aerial view of the Sangtarashan region and location of the site at the north of

6 the Sangtarashan village, b) Photo of the excavated area from the northern mountain,

7 showing remains of the circular architecture of the Iron Age sanctuary, c) Architectural

8 plan of Iron Age sanctuary discovered in six seasons of excavations at Sangtarashan.

$9 \quad$ Figure 3- a and b) Two examples of associated groups of bronze artefacts (caches)

10 discovered during the first season of excavations at Sangtarashan, c) Drawing of some

11 types of Sangtarashan bronze artefacts including vessels, axe-heads and sculptural artefacts.

12 Figure 4- Some metallic vessels and their selected samples analysed in this study.

13 Figure 5-Scatter plots of the concentrations of the main metallic elements in the

14 composition of the Sangtarashan bronzes and copper alloys from other archaeological sites

15 from Iron Age Iran, a and b) general and reduced range for $\mathrm{Cu}$ versus $\mathrm{Sn}, \mathrm{c}$ and d) general 4

16 and reduced range for $\mathrm{Sn}$ versus $\mathrm{As}$, e and f) general and reduced range for $\mathrm{Sn}$ versus $\mathrm{Pb}$.

17 Figure 6- Scatter plots of trace element concentrations in the composition of the

18 Sangtarashan bronzes and other archaeological sites from the Iron Age of Iran, a) Ag versus

$19 \mathrm{Ni}, \mathrm{b})$ As versus $\mathrm{Sb}$. The reduced range scatter plots are provided to present potential

20 correlations in details.

21 Figure 7- Three-isotope plot showing lead isotope ratios of the Sangtarashan samples.

22 Three outlier samples are marked in the lead isotope graphs.

23 Figure 8- Three-isotope plots of lead isotope ratios for Sangtarashan and data available for

24 archaeological sites (including copper alloys, slag, matte) and ore deposits from Iran, a and

25 b) full isotope ratio range of all available data based on Table 5, c and d) reduced isotope

26 ratio range of Sangtarashan artefacts and objects from other archaeological sites/collection,

27 e and f) reduced isotope ratio range of Sangtarashan samples and ore deposits from the

28 Iranian Plateau. 